\title{
Pengaruh Corporate Social Responsibility terhadap Kinerja Perusahaan Sektor Pertambangan Terdaftar di Bursa Efek Indonesia\&Malaysia 2014-2018
}

\author{
Irbahiya Aqsa Griselda \\ Fakultas Bisnis dan Ekonomika Universitas Surabaya \\ irbahiyagrisel@gmail.com \\ Werner R. Murhadi \\ Fakultas Bisnis dan Ekonomika Universitas Surabaya \\ wernermurhadi@gmail.com \\ Mudji Utami \\ Fakultas Bisnis dan Ekonomika Universitas Surabaya \\ mudjiutami@gmail.com
}

\begin{abstract}
The aims of this research is to analyze the effect of corporate social responsibility, leverage, firm size and firm size towards firm performance using return on assets and Tobin's Q as a proxy in mining sector companies listed in Indonesian Stock Exchange and Malaysia Stock Exchange in the period 2014-2018. This research uses quantitative approach with two least square regression analysis model. This study uses sample of firms which are listed on mining in IDX and MYX on 2014-2018. The findings result of this research CSR have positive and significant effect towards firm performance in mining sector companies BEI on the period 2014-2018, while CSR insignificant effect towards firm performance in mining sector companies BEM on the period 2014-2018.
\end{abstract}

Keywords: corporate social responsibility, financial performance, firm value

\section{LATAR BELAKANG}

Seiring perkembangan zaman, perusahaan dituntut untuk terus bersaing agar dapat terus meningkatkan reputasi perusahaan. Tak jarang jika perusahaan tidak mempedulikan lingkungan sekitarnya. Perusahaan seharusnya tidak hanya berfokus pada masalah keuangan saja, akan tetapi juga memperhatikan mengenai dampak sosial dan lingkungan hidup yang diakibatkan oleh aktivitas perusahaan (Untung, 2008). Kepedulian terhadap lingkungan dan sosial sekitar merupakan salah satu hal yang dapat membuat reputasi perusahaan semakin baik. Melalui Corporate Social Responsibility (CSR) perusahaan dapat mendukung keberlangsungan perusahaan itu sendiri. CSR dapat membuat sebuah reputasi yang baik bagi perusahaan di dalam 
benak konsumen dan pemegang saham, dan juga dapat meningkatkan efisiensi dari karyawan, mengarah pada seluruh performa yang lebih baik untuk perusahaan (Misha dan Suar, 2010).

Corporate Social Responsibility (CSR) merupakan isu yang mulai diperhatikan di kawasan Asia, khususnya di Asia Tenggara. Penelitian tentang CSR masih sedikit dan jarang di negara-negara yang dianggap berkembang dan lebih miskin (Belal, 2001). CSR dapat meningkatkan laba perusahaan secara tidak langsung melalui kinerja perusahaan (Ayu Dwi et al., 2014).

\section{Tabel 1}

\begin{tabular}{cc} 
Pengungkapan (Negara) & Corporate Social Responsibility \\
\hline Negara & Total Presentase \\
\hline Malaysia & $97 \%$ \\
Indonesia & $93 \%$ \\
Singapura & $84 \%$ \\
Thailand & $67 \%$ \\
\hline
\end{tabular}

sumber: KPMG Survey of CSR 2017

Semakin besar perusahaan mengeruk sumber daya alam maka mempunyai risiko merusak lingkungan yang semakin besar pula. Jika dilihat dari pengungkapan terhadap CSR dari setiap negara, maka penulis memutuskan untuk meneliti lebih lanjut tentang pengungkapan CSR di Indonesia dan Malaysia dikarenakan pengungkapan CSR di Malaysia tergolong paling tinggi diantara negara-negara di Asia Tenggara yang lain yaitu sebesar 97\% dan Indonesia memiliki nilai 93\%. Data pada KPMG (2017) menunjukkan bahwa sektor minyak dan gas merupakan sektor terbesar dalam pengungkapan CSR, yaitu sebesar $81 \%$, sedangkan sebesar $80 \%$ dimiliki oleh sektor pertambangan. Jika dilihat, minyak dan gas termasuk dalam sektor pertambangan.

Teori stakeholder menyatakan bahwa perusahaan tidak hanya beroperasi untuk kepentingan sendiri, akan tetapi harus memberikan sebuah manfaat bagi stakeholder (Widianto, 2011). Widianto (2011) menyataka bahwa dukungan dari stakeholder sangatlah penting untuk kelangsungan hidup perusahaan, semakin kuat dukungan yang diberikan, maka akan semakin besar pula usaha perusahaan untuk beradaptasi.

CSR terhadap Kinerja Perusahaan

Nyeadi et al., (2018) dan Feng et al., (2017) menunjukkan bahwa praktik CSR (corporate social responsibility) yang dilakukan oleh perusahaan memiliki hubungan yang positif dengan kinerja perusahaan. Mishra dan Suar (2010), mengatakan bahwa jika perusahaan memiliki tanggung jawab secara sosial, maka pekerja secara tidak langsung juga akan bermental positif terhadap perusahaan. Dengan kata lain, perusahaan yang menjalankan tanggung jawab sosial akan membuat efisiensi dan produktivitas tenaga kerja lebih tinggi. Mishra dan Suar (2010) Jika dilihat melalui 
hubungan pelanggan, pelanggan akan lebih percaya dengan produk yang dikeluarkan oleh perusahaan yang mempunyai identitas yang jelas dengan mengaitkan perusahaan dengan kegiatannya. Sehingga hal tersebut akan berdampak pada kinerja perusahaan yang semakin baik.

$\mathrm{H}_{1}$ : Corporate social responsibility berpengaruh positif terhadap kinerja perusahaan.

Leverage terhadap Kinerja Perusahaan

Tingkat utang yang tinggi akan menyebabkan tingginya tingkat kebangkrutan (financial distress), disebabkan ketika perusahaan tidak mampu membayar pokok utang dan beban dari utang tersebut yang akan berdampak negatif pada kinerja keuangan (Salim dan Yadav, 2012). Hal ini dapat dikatakan bahwa utang dapat berpengaruh negatif terhadap kinerja keuangan.

$\mathrm{H}_{2}$ : Leverage berpengaruh negatif terhadap kinerja perusahaan.

Firm Size terhadap Kinerja Perusahaan

Varun Dawar (2014) menyatakan bahwa perusahaan yang mempunyai ukuran lebih besar akan lebih mampu untuk mempengaruhi produk dan pasar yang lebih besar dan akan meningkatkan kinerja dari perusahaan. Hal ini menyatakan bahwa ukuran perusahaan mempunyai dampak positif terhadap kinerja keuangan.

$\mathrm{H}_{3}$ : Firm size berpengaruh positif terhadap kinerja perusahaan.

Firm Age terhadap Kinerja Perusahaan

Coad et al., (2010) menyatakan bahwa umur perusahaan akan berpengaruh terhadap produktivitas. Semakin lama perusahaan berdiri maka semakin produktif perusahaan tersebut, laba perusahaan akan meningkat, ukuran perusahaan akan semakin besar, rasio utang yang lebih rendah, dan rasio ekuitas yang semakin tinggi. Selain itu, perusahaan yang lebih tua akan mampu mengubah pertumbuhan penjualan menjadi pertumbuhan laba dan produktivitas (Coad et al., 2010). Hal ini dapat dikatakan bahwa umur perusahaan akan berdampak positif terhadap kinerja keuangan.

$\mathrm{H}_{4}$ : Firm age berpengaruh positif terhadap kinerja perusahaan.

\section{METODE PENELITIAN}

Penelitian ini merupakan jenis penelitian basic research. Basic research adalah sebuah penelitian yang bertujuan untuk mengembangkan penelitian yang sudah dilakukan sebelumnya. Berdasarkan tujuan penelitian, penelitian ini merupakan jenis causal research yaitu sebuah penelitian yang dilakukan untuk membuktikan adanya hubungan sebab akibat dari variabel-variabel yang ada dalam penelitian. Tujuan dari penelitian ini yaitu untuk mengetahui adanya pengaruh corporate social responsibility terhadap kinerja perusahaan.

Objek yang akan digunakan dalam penelitian ini adalah badan usaha sektor pertambangan yang terdaftar di Bursa Efek Indonesia dan Malaysia selama periode 
2014-2018, menerbitkan laporan tahunan yang lengkap dan telah diaudit selama periode 2014-2018, memiliki data seluruh variabel yang dibutuhkan lengkap selama periode 2014-2018, dan memiliki nilai ekuitas bertanda positif selama periode 20142018.

Jenis data yang digunakan dalam penelitian ini adalah data sekunder atau data historis karena data yang diperoleh dari website Bursa Efek Indonesia dan Bursa Efek Malaysia melalui www.idx.co.id, www.bursamalaysia.com dan website masingmasing perusahaan sektor pertambangan periode 2014-2018 berupa laporan keuangan dan laporan tahunan perusahaan.

Penelitian ini menggunakan metode pengolahan data regresi linear berganda untuk mengetahui pengaruh variabel independen terhadap variabel dependen. Variabel dependen dalam penelitian ini adalah kinerja perusahaan yang dihitung dengan menggunakan financial performance (ROA) dan firm value (Tobin's Q), sedangkan variabel independennya yaitu corporate social responsibility dengan variabel kontrolnya adalah leverage, firm size dan firm age. Sehingga persamaan yang digunakan adalah berikut ini:

$\mathrm{ROA}_{i t}=\alpha+\beta_{1} \cdot \mathrm{CSR}_{\mathrm{it}}-\beta_{2} \cdot \mathrm{LEV}_{\mathrm{it}}+\beta 3 . \mathrm{SIZE}_{\mathrm{it}}+\beta_{4} \cdot \mathrm{AGE}_{\mathrm{i}}$

$\mathrm{TQ}_{\text {it }}=\alpha+\beta_{1} . \mathrm{CSR}_{-} \mathrm{I}_{\mathrm{it}}-\beta_{2} \cdot \mathrm{LEV}_{\mathrm{it}}+\beta 3 . \mathrm{SIZE}_{\mathrm{it}}+\beta_{4} \cdot \mathrm{AGE}_{\mathrm{it}}$

Keterangan:

$\mathrm{ROA}_{\text {it }}$ : Return on assets pada perusahaan i periode $\mathrm{t}$

TQ $\quad$ : Tobin's $\mathrm{Q}$ pada perusahaan i periode $\mathrm{t}$

CSR_I $I_{i t}$ : Indeks Corporate social responsibility pada perusahaan i periode $t$

$\mathrm{LEV}_{\text {it }}$ : Rasio hutang terhadap aset perusahaan i periode $\mathrm{t}$

$\mathrm{SIZE}_{\mathrm{it}}$ : Firm size perusahaan i periode $\mathrm{t}$

$\mathrm{AGE}_{\mathrm{it}}$ : Firm age perusahaan i periode $\mathrm{t}$

$\alpha \quad$ : Koefisien konstan

$\beta \quad$ : Koefisien regresi

\section{HASIL DAN DISKUSI}

Penelitian ini menggunakan perusahaan sektor pertambangan yang terdaftar di BEI dan BEM periode 2014-2018. Terdapat total 26 perusahaan dengan 130 total observasi yang memenuhi kriteria di Indonesia. Sedangkan di Malaysia terdapat total 17 perusahaan dengan 85 total observasi yang memenuhi kriteria.

Tabel 2

Statistik Deskriptif Indonesia

\begin{tabular}{lllllll}
\hline & $\mathrm{N}$ & Mean & Median & Maxiumum & Minimum & Std. Deviation \\
\hline ROA & 130 & 0.056220 & 0.034088 & 0.455579 & -0.162714 & 0.090279 \\
TQ & 130 & 1.339712 & 1.013111 & 8.123791 & 0.454057 & 1.029902 \\
CSR & 130 & 0.005963 & 0.001720 & 0.110041 & 0.000049 & 0.012562 \\
\hline
\end{tabular}




\begin{tabular}{lllllll}
\hline LEV & 130 & 0.457183 & 0.426524 & 0.971474 & 0.097790 & 0.184515 \\
SIZE & 130 & 29.52135 & 29.35475 & 32.27410 & 26.62389 & 1.306060 \\
AGE & 130 & 28.84615 & 27.50000 & 68.00000 & 7.000000 & 14.78186 \\
\hline
\end{tabular}

(Sumber: Pengolahan data dengan Eviews 10)

Pada tabel 2, variabel ROA (Return on Assets), nilai maximum diperoleh dari perusahaan BYAN (2018) dan nilai minimum diperoleh dari perusahaan BYAN (2014). Pada variabel TQ (Tobin's Q), nilai maximum dan minimum masing-masing di peroleh dari perusahaan SMMT (2014) dan ARTI (2017). Pada variabel CSR (Corporate Social Responsibility), nilai maximum dan minimum masing-masing di peroleh dari perusahaan SMMT (2014) Dan GEMS (2014). Pada variabel LEV (Leverage), nilai maximum dan minimum masing-masing di peroleh dari ARII (2018) dan HRUM (2015). Pada variabel SIZE (Firm Size) nilai maximum dan minimum masing-masing di peroleh dari perusahaan ADRO (2018) dan CTTH (2014). Pada variabel AGE (Firm Age), nilai maximum dan minimum masing-masing di peroleh dari PTBA (2018) dan ARII, BIPI, TOBA (2014).

Tabel 3

Statistik Deskriptif Malaysia

\begin{tabular}{lllllll}
\hline & $\mathrm{N}$ & Mean & Median & Maxiumum & Minimum & Std. Deviation \\
\hline ROA & 85 & -0.021119 & 0.017285 & 0.254585 & -0.568510 & 0.126410 \\
TQ & 85 & 0.976398 & 0.884159 & 2.911771 & 0.441117 & 0.405065 \\
CSR & 85 & 0.003223 & 0.000978 & 0.042954 & 0.000073 & 0.006295 \\
LEV & 85 & 0.518599 & 0.533135 & 0.912288 & 0.064095 & 0.175635 \\
SIZE & 85 & 29.56218 & 29.68052 & 32.41319 & 27.03297 & 1.095758 \\
AGE & 85 & 25.88235 & 26.00000 & 58.00000 & 10.00000 & 11.34881 \\
\hline
\end{tabular}

(Sumber: Pengolahan data dengan Eviews 10)

Pada tabel 3, variabel ROA (Return on Assets), nilai maximum diperoleh dari perusahaan HENGYUAN (2017) dan nilai minimum diperoleh dari perusahaan ICON (2018). Pada variabel TQ (Tobin's Q), nilai maximum dan minimum masingmasing di peroleh dari perusahaan DIALOG (2014) dan SUMATEC (2018). Pada variabel CSR (Corporate Social Responsibility), nilai maximum dan minimum masing-masing di peroleh dari perusahaan SUMATEC (2018) dan SCOMI (2015). Pada variabel LEV (Leverage), nilai maximum dan minimum masing-masing di peroleh dari DELEUM (2017) dan SUMATEC (2015). Pada variabel SIZE (Firm Size) nilai maximum dan minimum masing-masing di peroleh dari perusahaan SAPNRG (2017) dan T7GLOBAL (2015). Pada variabel AGE (Firm Age), nilai maximum dan minimum masing-masing di peroleh dari HENGYUAN (2018) dan T7GLOBAL (2014). 
Setelah melakukan uji chow dan uji hausman dengan $\alpha=5 \%$, dengan tingkat keyakinan 95\% bahwa fixed effect lebih baik daripada random effect. Fixed effect digunakan baik di Indonesia maupun Malaysia

\section{Tabel 4}

Hasil Uji Regresi Kinerja Keuangan Indonesia

\begin{tabular}{lllllll}
\hline \multirow{2}{*}{ Variabel } & ROA & \multicolumn{5}{l}{ Tobin's Q } \\
Coeff. & $\mathrm{t}$ & Prob. & Coeff. & $\mathrm{t}$ & Prob. \\
\cline { 2 - 7 } CSR & -1.992194 & -2.703904 & 0.0081 & 7.159281 & 3.548936 & 0.0006 \\
Leverage & -0.384904 & 1.696075 & $0.0930^{*}$ & 37.48213 & 4.493572 & $0.0000^{* * *}$ \\
Firm Size & 0.065718 & -4.847049 & $0.0000^{* * *}$ & -0.244822 & -1.855850 & $0.0664^{*}$ \\
Firm Age & 0.008698 & 2.423846 & $0.0062^{* * *}$ & -0.217596 & -2.994421 & $0.0035^{* * *}$ \\
\hline
\end{tabular}

(Sumber: Pengolahan data dengan Eviews 10)

Keterangan $\quad: * \quad$ : signifikan pada $10 \%$

$* * \quad$ : signifikan pada $5 \%$

$* * * \quad$ : Signifikan pada $1 \%$

Pada tabel 3, menunjukkan bahwa CSR berpengaruh signifikan positif di Indonesia terhadap ROA maupun Tobin's Q. Hal ini sejalan dengan penelitian Nyeadi et al (2018) dan Feng et al (2017) menemukan corporate social responsibility mempunyai pengaruh signifikan positif terhadap kinerja perusahaan. Martin et al. (2009) menemukan bahwa CSR dapat dijadikan keuntungan jangka panjang untuk perusahaan karena membantu untuk mengembangkan dan mempertahankan reputasi perusahaan dan memperkuat komitmen kepada para pemangku kepentingan. Feng et al. (2017) menyatakan bahwa CSR dapat membantu mempromosikan adanya manfaat sosial eksternal seperti niat baik terhadap publik di luar perusahaan dan meningkatkan reputasi perusahaan yang berakibat terhadap naiknya nilai perusahaan.

Hasil penelitian menujukkan bahwa variabel leverage berpengaruh positif signifikan terhadap ROA maupun Tobin's Q. Hal ini sejalan dengan hipotesis awal yang menyatakan bahwa leverage berpengaruh signifikan negatif terhadap kinerja perusahaan. Hal ini didukung oleh penelitian Sheikh dan Wang (2013) menyatakan bahwa perusahaan yang menggunakan utang yang cenderung tinggi dapat melemahkan peran manajer dalam mengambil keputusan untuk meningkatkan kinerja perusahaan. Manajer tidak akan leluasa untuk beroperasi secara bebas karena adanya pengaruh pengawasan kreditur yang ketat, sehingga berdampak pada keunungan yang diperoleh oleh perusahaan (Vatavu, 2015).

Hasil penelitian menunjukkan bahwa variabel firm size berpengaruh positif signifikan terhadap ROA. Hal ini sejalan dengan hipotesis awal. Hal ini didukung oleh Varun Dawar (2014) menyatakan bahwa perusahaan yang mempunyai ukuran lebih besar akan lebih mampu untuk mempengaruhi produk dan pasar yang lebih besar dan akan meningkatkan kinerja dari perusahaan. Selain itu, hasil penelitian menunjukkan bahwa variabel firm size berpengaruh negatif signifikan terhadap 
Tobin's Q. Hal ini didukung oleh penelitian Nyeadi et al. (2018) dan Feng et al. (2017) menemukan bahwa firm size memiliki pengaruh signifikan negatif terhadap Tobin's Q. Qomariah (2015) menemukan bahwa ukuran perusahaan penting untuk dijadikan pertimbangan bagi investor untuk melakukan investasi, sebab semakin besar perusahaan maka risiko yang dihadapi perusahaan juga semakin besar.

Hasil penelitian menunjukkan bahwa variabel firm age berpengaruh positif signifikan terhadap ROA dan Tobin's Q. Hal ini sejalan dengan hipotesis awal yang menyatakan bahwa firm age berpengaruh signifikan positif terhadap kinerja perusahaan. Hal ini didukung oleh penelitian Nyeadi et al., (2018) menemukan bahwa firm age memiliki pengaruh signifikan positif terhadap Tobin's Q. Hal ini didukung oleh penelitian yang dilakukan oleh Zen dan Herman (2007) yang menyatakan bahwa perusahaan dengan umur yang lebih tua membuat investor semakin percaya dan menarik investor untuk menanamkan modalnya dibandingkan dengan perusahaan dengan umur yang lebih muda (baru berdiri), sebab perusahaan yang lebih lama berdiri diasumsikan akan menghasilkan laba yang lebih tinggi dibandingkan perusahaan baru. Pickernell (2013) menyatakan bahwa perusahaan yang lebih muda memiliki penjualan yang lebih sedikit dari pada perusahaan yang lebih tua. Perusahaan tua mempunyai penjualan yang lebih besar, yang berakibat pada peningkatan profitabitias perusahaan.

\section{Tabel 5}

\section{Hasil Uji Regresi Kinerja Keuangan Malaysia}

\begin{tabular}{|c|c|c|c|c|c|c|}
\hline \multirow{2}{*}{ Variabel } & \multicolumn{3}{|l|}{ ROA } & \multicolumn{3}{|l|}{ Tobin's Q } \\
\hline & Coeff. & $\mathrm{t}$ & Prob. & Coeff. & $\mathrm{t}$ & Prob. \\
\hline C & -3.138401 & -4.953300 & 0.0000 & 11.60510 & 7.920665 & 0.0000 \\
\hline CSR & 0.401181 & 0.292907 & 0.7705 & -3.205311 & -0.966135 & 0.3376 \\
\hline Leverage & -0.132211 & -15.42264 & $0.0000 * * *$ & 0.516849 & 10.70368 & $0.0000 * * *$ \\
\hline Firm Size & 0.132211 & 6.169070 & $0.0000 * * *$ & -0.282811 & -5.548012 & $0.0000 * * *$ \\
\hline Firm Age & -0.023085 & -16.18856 & $0.0000 * * *$ & -0.097592 & -13.85668 & $0.0000 * * *$ \\
\hline
\end{tabular}

(Sumber: Pengolahan data dengan Eviews 10)

Keterangan $\quad: * \quad$ : signifikan pada $10 \%$

** $\quad$ : signifikan pada $5 \%$

*** $\quad$ : Signifikan pada $1 \%$

Pada tabel 4, menunjukkan bahwa CSR tidak memiliki pengaruh terhadap ROA maupun Tobin's Q. Hal ini sejalan dengan penelitian Crisostomo et al (2011) yang menemukan bahwa CSR tidak memiliki pengaruh terhadap ROA. Hal ini didukung oleh penelitian Bratenius dan Melin (2015) menemukan bahwa CSR tidak memiliki pengaruh terhadap Tobin's Q. Hal ini diperkuat dengan penelitian Nkundabanyanga (2011) yang menyatakan bahwa adanya tekanan hukum, sosial dan ekonomi dalam mendorong perilaku yang bertanggung jawab secara sosial sehingga kegiatan CSR dilakukan dengan terpaksa. Maka dari itu, banyak manipulasi yang dilakukan oleh perusahaan tentang kegiatan tanggung jawab sosial (Christie dan Geis, 1970 dalam 
Nkudabanyanga 2011). Namun bertentangan dengan hipotesis awal maupun penelitian Nyeadi et al (2018) dan Feng et al (2017).

Hasil penelitian menujukkan bahwa variabel leverage berpengaruh negatif signifikan terhadap ROA. Tingkat utang yang tinggi akan menyebabkan tingginya tingkat kebangkrutan (financial distress), disebabkan ketika perusahaan tidak mampu membayar pokok utang dan beban dari utang tersebut yang akan berdampak negatif pada kinerja keuangan (Salim dan Yadav, 2012). Selain itu, hasil penelitian menunjukkan bahwa variabel leverage berpengaruh positif signifikan terhadap Tobin's Q. Peningkatan leverage merupakan sinyal kepada pihak eksternal sebagai kemampuan perusahaan untuk membayar kewajiban dan bunga di masa yang akan datang dan adanya risiko bisnis yang rendah, maka sinyal tersebut akan direspon positif oleh pasar (Brigham dan Houston, 1999).

Hasil penelitian menunjukkan bahwa variabel firm size berpengaruh positif signifikan terhadap ROA. Hal ini didukung oleh Varun Dawar (2014) menyatakan bahwa perusahaan yang mempunyai ukuran lebih besar akan lebih mampu untuk mempengaruhi produk dan pasar yang lebih besar dan akan meningkatkan kinerja dari perusahaan. Selain itu, hasil penelitian menunjukkan bahwa variabel firm size berpengaruh negatif signifikan terhadap Tobin's Q. Hal ini sejalan dengan penelitian Qomariah (2015) menemukan bahwa ukuran perusahaan penting untuk dijadikan pertimbangan bagi investor untuk melakukan investasi, sebab semakin besar perusahaan maka risiko yang dihadapi perusahaan juga semakin besar.

Hasil penelitian menunjukkan bahwa variabel firm age berpengaruh negatif signifikan terhadap ROA maupun Tobin's Q. Hal ini didukung oleh penelitian Nyeadi et al., (2018) menemukan bahwa firm age memiliki pengaruh signifikan negatif terhadap ROA dan sejalan dengan penelitian yang dilakukan oleh Feng et al., (2017) menemukan bahwa firm age mempunyai pengaruh signifikan negatif terhadap Tobin's Q namun bertentangan dengan hipotesis awal. Pervan et al. (2017) menyatakan bahwa semakin lama perusahaan berdiri, maka perusahaan akan semakin birokratis, fleksibilitas perusahaan semakin berkurang dan cenderung tidak berubah dan menghindari risiko. Perusahaan tidak berani melangkah lebih jauh dan berakibat pada nilai perusahaan yang semakin menurun. Perusahaan yang lebih tua menjadi lebih kaku, daya saing lebih rendah, kemampuan, pengetahuan dan ketrampilan menjadi usang dan berdampak pada penurunan profitabilitas organisasi (Leonard dan Barton, 1992).

\section{KONKLUSI}

Dari hasil analisis regresi dengan menggunakan software Eviews 10 yang telah diolah dan dibahas sebelumnya. Hasil dari penelitian ini menunjukkan bahwa CSR mempunyai pengaruh signifikan positif terhadap kinerja perusahaan di Indonesia. Akan tetapi tidak mempunyai pengaruh terhadap kinerja perusahaan di Malaysia. Hal ini disebabkan karena hukum yang diterapkan di Indonesia dan Malaysia berbeda. Hal tersebut berdampak pada pelaporan kegiatan CSR perusahaan di laporan keuangan tahunan. 
Sedangkan untuk variabel kontrol yang terdiri dari leverage, firm size, dan firm age memiliki hasil yang sigifikan terhadap kinerja perusahaan baik nilai buku (return on asset) ataupun dengan nilai perusahaan (Tobin's Q). Hasil ini terbukti baik di Indonesia dan Malaysia.

\section{REFERENCES}

Ayu, D. Siti \& Nila. (2014). Pengaruh Corporate Social Responsibility (CSR) Terhadap Financial Performance Dan Firm Value (Studi pada PeruusahaanPerusahaan yang Terdaftar Pada Indeks SRI KEHATI Periode 2010-2012). Jurnal Administrasi Bisnis (JAB). 14(1), 1-10.

Belal, A. R. (2001). A Study of Corporate Social Disclosure in Bangladesh. Managerial Auditing Journal. 16(5). 274-289.

Bratenius, Anna \& Melin. 2015. The Impact of CSR on Financial Performance. MSc Accounting (Master Thesis). Strategy \& Control Copenhagen Business School.

Brigham, E. F \& J. F. Weston. 1999. Dasar-dasar Manajemen Keuangan. Edisi 9, Erlangga

Coad A., Segarra \& Mercedes. 2010. Like milk or wine: Does firm performance improve with age?. Papers on Economics and Evaluation, 1006.

Crisostomo, V.L., Freire, F.S., \& Vasconcellos, F.C. (2011). Corporate Social Responsibility, Firm Value and Financial Performance in Brazil. Social Responsibility Journal, 7, 295-309. DOI:10.1108/17471111111141549.

Feng, M., Xiao \& Wang, \& Kreuze, J.G. (2017). Corporate Social Responsibility and Firm Financial Performance: Comparison Analyses Across Industries and CSR Categories. American Journal of Business, 32(3/4), 106-133. DOI:10.1108/AJB05-2016-0015.

KPMG. (2017). The road ahead: The KPMG survey of corporate responsibility reporting 2017 [Online]. Tersedia di: https://assets.kpmg.com/content/dam/kpmg/xx/pdf/2017/10/kpmg-surveyofcorporate-responsibility-reporting-2017.pdf

Leonard-Barton, D. (1992). Core capabilities and core rigidities: A paradox in managing new product development. Strategic Management Journal. 13, 111125.

Martin, J., Petty, W. \& Wallace, J. (2009). Shareholder value maximization - is there a role for corporate social responsibility?, Journal of Applied Corporate Finance, 21(2), 110-118.

Mishra, S. \& Suar, D. (2010). Does corporate social responsibility Influence financial performance in Indian companies?. Journal of Business Ethics. 95(4). 571-601.

Nkundabanyanga, S., \& Alfred O. (2011). Institutionalizing corporate social responsibility (CSR) in Uganda: does it matter?. Social Responsibility Journal, $7(4), 665-680$.

Nyeadi, J.D., Ibrahim, M. \& Sare, Y.A. (2018). Corporate Social Responsibility and Financial Performance Nexus: Empirical Evidence From South African Listed 
Firm. Journal of Global Responsibility 9(3), 301-328. DOI:10.1108/JGR-012018-0004.

Pervan,M., Ivica P., \& Marijana C. (2017). The Influence of Age on Firm Performance: Evidence from the Croatian Food Industry. Journal of Eastern Europe Research in Business and Economics. 2017, 1-10 University of Split. Croatia.

Pickernell, D. (2013). New and young fifirms Entrepreneurship policy and the role of government - evidence from the Federation of Small Businesses survey. Journal of Small Business and Enterprise Development, 20(2), 358-382.

Qomariah, N. (2015). The Effect of Corporate Social Responsibility, Size and Profitability Towad on The Value of Corporate (Studies in Manufacturing Companies Listed in Indonesia Stock Exchange). Journal of Business and Management, 17(2), 25-30.

Salim dan Yadav. (2012). Capital structure and firm performance: Evidence from Malaysian listed companies. Procedia-Social and Behavioral Sciences.

Sheikh, N.A. \& Wang, Z. (2011). Determinants of Capital Structure: An Empirical Study of Firms in Manufacturing Industry of Pakistan. Managerial Finance. 37(2), 117-133.

Varun, D. (2014). Agency Theory, Capital Structure and Firm Performance: Some Indian Evidence. Emerald Insight. Managerial Finance, 40(12), 1190 - 1206.

Vatavu, S. (2015). The Impact Of Capital Structure On Financial Performance In Romanian Listed Companies. Procedia Economics and Finance, 32, 1314-1322.

Widianto, H.S. (2011). Pengaruh Profitabilitas, Likuiditas, Leverage, Aktivitas, Ukuran Perusahaan, dan Corporate Governance terhadap Praktik Pengungkapan Sustainability Report (Skripsi). Fakultas Ekonomika dan Bisnis Universitas Diponegoro.

Zen, S.D. \& Herman, M. (2007). Pengaruh Harga Saham, Umur Perusahaan, dan Rasio Profitabilitas Perusahaan Terhadap Tindakan Perataan Laba Yang Dilakukan Oleh Perusahaan Perbankan Yang Terdaftar di Bursa Efek Jakarta. Jurnal Akuntansi dan Manajemen, 2, 57- 71. 